\title{
THE LIGHT-HARVESTING COMPLEX OF PHOTOSYSTEM II IN BARLEY. STRUCTURE AND CHLOROPHYLL ORGANIZATION
}

\author{
by \\ URSULA G. HINZ ${ }^{1)}$ \\ and \\ KAREN G. WELINDER ${ }^{2)}$ \\ Department of Physiology, Carlsberg Laboratory, \\ Gamle Carlsberg Vej 10, DK-2500 Copenhagen, Valby \\ and \\ 2) Institute of Biochemical Genetics, University of Copenhagen, \\ Øster Farimagsgade 2A, DK-1353 Copenhagen K \\ 1) present address: Friedrich Miescher-Institut, \\ P.O. Box 2543, CH-4002 Basel, Switzerland
}

\begin{abstract}
Keywords: Amino acid sequence determination, chlorophyll content, circular dichroism, denaturation, oligomeric structure, proteolytic digestion
\end{abstract}

\begin{abstract}
The isolated light-harvesting complex of photosystem II (LHCII) in barley had a chlorophyll (Chl) $a / b$ ratio of $1.37(\mathrm{~mol} / \mathrm{mol})$ and contained an average of $13.1 \mathrm{Chl}$ molecules per $25 \mathrm{kD}$ polypeptide chain, corresponding to 7.6 molecules of $\mathrm{Chl} a$ and 5.5 molecules of $\mathrm{Chl} b$. Tryptic digestion of native LHCII yielded a $16 \mathrm{kD}$ fragment which contained 12 of these $13 \mathrm{Chl}$ molecules. The $16 \mathrm{kD}$ fragment started with the serine 52 of the mature polypeptide, as determined by $\mathrm{N}$-terminal amino acid sequence analysis and comparison with the amino acid sequence deduced from the nucleotide sequence of a corresponding gene in wheat (LAMPPA et al. 1985). Circular dichroism measurements of $\mathrm{LHCII}$ in $1 \%$ SDS or at extremes of $\mathrm{pH}$, showed that there were at least two populations of $\mathrm{Chl} a$ and that $\mathrm{Chl} a$ was much more sensitive to changes in the aqueous environment than $\mathrm{Chl} b$. We present a model for the folding of LHCII with four transmembrane helices, based on the above results and on the application of the rules of CHOU and FASMAN (1978) and PAUL and ROSENBUSCH (1985) for the prediction of secondary structure using the wheat sequence.
\end{abstract}

\section{l. INTRODUCTION}

The light-harvesting complex of photosystem II (LHCII) in maize is composed of at least five polypeptides with slightly different mobilities during SDS-PAGE (5). Analyses of the nuclear genome in tomato and petunia have shown that the genes coding for polypeptide components of LHCII are present in several copies and organized in five small multigene families $(12,26)$. The amino acid sequences deduced from the

\footnotetext{
Abbreviations: $\mathrm{CD}=$ circular dichroism; $\mathrm{Chl}=$ chlorophyll; $\mathrm{DTT}=$ dithiothreitol; $\mathrm{HPLC}=$ high pressure liquid chromatography; LHCII = light-harvesting complex of photosystem II; PAGE = polyacrylamide gel electrophoresis; PSII = photosystem II; PTH = phenylthiohydantoin; RC = reaction center complex; SDS = sodium dodecyl sulfate; Tricine $=\mathrm{N}($ tris(hydroxymethyl)methyl)glycine.
} 
nucleotide sequences of these different genes were more than $90 \%$ identical, and the differences were concentrated in the $\mathrm{N}$-terminus. It is thus very likely that the amino acid sequences of the component polypeptides of LHCII in barley also differ mainly at their $\mathrm{N}$-termini.

LHCII is accessible to antibodies from both sides of the thylakoid membrane (2) and the $\mathrm{N}$-terminal part of the major (i.e., most abundant) polypeptide from $\mathrm{LHCII}$ has been shown to be involved in membrane stacking (21). Circular dichroism and polarized infrared spectroscopy have indicated that LHCII has a mainly $\alpha$-helical conformation (23). Analysis of twodimensional crystals has revealed that oligomeric LHCII has a three-fold symmetry axis and three or four transmembrane helices per monomer $(16,19)$. Excitation energy transfer between Chl molecules occurs with almost $100 \%$ efficiency within the complex and the pigments are protected against contact with the aqueous environment by the folding of the polypeptide chain (29). Circular dichroism spectra in the visible range suggested that the $\mathrm{Chl} b$ molecules in LHCII isolated by preparative SDS-PAGE were arranged round a three-fold symmetry axis $(28,30)$.

Despite this information, it is not known which parts of the polypeptide chain are in contact with the water phase and which are buried in the membrane, or which residues are involved in pigment co-ordination. In this investigation, circular dichroism spectra of trypsinized LHCII and LHCII exposed to SDS or extremes of $\mathrm{pH}$ were used to study the organization of the pigments. We present a model of LHCII based on proteolytic digestion patterns and sequencing data, using the methods of CHOU and FASMAN (10) and PAUL and ROSENBUSCH (24) for the prediction of secondary structure.

\section{MATERIALS AND METHODS}

\subsection{Biological preparations}

Wild type barley seedlings (Hordeum vulgare cv. Svalöfs Bonus) were grown for 7 days in vermiculite under $16 \mathrm{~h}$ light and $8 \mathrm{~h}$ dark cycles. Thylakoids for SDS-PAGE were prepared as described by MACHOLD et al. (20).

\subsection{Isolation of $\mathrm{Chl}$-protein complexes}

Grana membranes were isolated using a modification of the Triton X-100 method of BERTHOLD et al. (7) as described by MøLLER and HøJ (22). The membranes were solubilized using dodecyl- $\beta, D$-maltoside and fractionated into water-soluble polypeptides derived from the oxygen-evolving site, LHCII, and the reaction center complex of photosystem II (RC) by centrifugation on $10-30 \%$ sucrose gradients containing $10 \mathrm{~mm}$-Tricine, $\mathrm{pH} 8.0$ and $0.025 \%$ Triton X-100 $(9,14)$.

\subsection{Electrophoresis}

Samples were completely denatured by boiling in $1 \%$ SDS, 5 mm-DTT, 5 mm- $\mathrm{NaHCO}_{3}$. SDS-PAGE was performed in gels containing 6 M-urea as described by PICCIONI et al. (25).

Non-denaturing SDS-PAGE of native samples was carried out using $1 \mathrm{~mm}$ thick slab gels containing $10,12.5$ or $15 \%$ polyacrylamide. Lowering the SDS concentration in the gel from 0.1 to $0.03 \%$ and changing the acrylamide: bisacrylamide ratio from $30: 0.8$ to $33: 1.1$ decreased the degree of dissociation of the Chlprotein complexes during electrophoresis. The gels were run at $4{ }^{\circ} \mathrm{C}$ using buffer system II (20). Proteins were visualized by staining with Coomassie Brilliant Blue R250 or the alkaline silver stain described by WrAY et al. (32).

\subsection{Proteolytic treatment}

Isolated LHCII $\left(0.5 \mathrm{mg} \mathrm{Chl} \cdot \mathrm{ml}^{-1}\right)$ was incubated at $4{ }^{\circ} \mathrm{C}$ with trypsin, (Type III), chymotrypsin (Type II, both from Sigma), Staphylococcus aureus protease $\mathrm{V} 8$, subtilisin A, pronase $\mathrm{E}$ or protease $\mathrm{K}$. The protease concentration varied between $20 \mu \mathrm{g} \cdot \mathrm{ml}^{-1}$ and $1 \mathrm{mg} \cdot \mathrm{ml}^{-1}$. The samples were incubated for $24 \mathrm{~h}$ when low amounts of protease were used, or $2.5 \mathrm{~h}$ when the protease concentration was high. LHCII was then separated from the protease by centrifugation on $10-30 \%$ sucrose gradients containing 10 mM-Tricine, $\mathrm{pH} 8.0$ and $0.025 \%$ Triton X-100 at $80.000 \times \mathrm{g}$ for $24 \mathrm{~h}$ or more. 


\subsection{Amino acid sequence determination}

After proteolytic treatment, degraded LHCII was purified by sucrose density gradient centrifugation as described above. The sample was boiled in $1 \%$ SDS, 5 mM-DTT to dissociate the complex into its component peptides, which were then purified by gel-filtration on an AcA 34 (LKB Ultrogel) column equilibrated in $0.05 \%$ SDS, $100 \mathrm{~mm}-\mathrm{NaHCO}_{3}$, pH 9.0, 0.5 mM-DTT.

Alternatively, the green Chl-protein band was excised from unstained gels after non-denaturing SDS-PAGE (section 2.3), the slices crushed and the protein eluted by twice incubating with five volumes of distilled water. The extract was lyophilized, redissolved in a small volume of distilled water and purified by gel-filtration as described above. The peptide fractions were lyophilized, and then redissolved in a small volume of distilled water prior to amino acid sequence analysis using an Applied Biosystems $470 \mathrm{~A}$ gas phase sequencer and the program O2NRUN. PTH-amino acids generated by the sequencer were identified by HPLC on a $4.6 \times 125 \mathrm{~mm}$ column of Spherisorb S5-ODS 2 (Phase Sep), using Waters equipment with 254 and $313 \mathrm{~nm}$ detectors.

\subsection{Spectroscopic measurements}

Absorption spectra were recorded on an Aminco DW2a spectrophotometer. Circular dichroism spectra in the visible range were recorded at room temperature using a Roussel-Jouen Dichrograph III equipped with a $1 \mathrm{~cm}$ quartz cell. For measurements between 260 and 200 $\mathrm{nm}$ a Cary 61 spectropolarimeter and a quartz cell with $0.5 \mathrm{~cm}$ pathlength was used. The optical density of the samples was adjusted to a value of about 1 at $670 \mathrm{~nm}$ for spectra between 350 and $750 \mathrm{~nm}$ and to about 0.3 for measurements in the ultraviolet range.

\subsection{Chlorophyll content}

The chlorophyll concentration was determined spectroscopically in $80 \%$ acetone as described by ARNON (3). Protein was quantitated by amino acid analysis after $24 \mathrm{~h}$ hydrolysis in $6 \mathrm{~N}-\mathrm{HCl}$ at $108{ }^{\circ} \mathrm{C}$ in evacuated, sealed tubes. Amino acid analyses were performed on a Durrum D-500 amino acid analyzer.

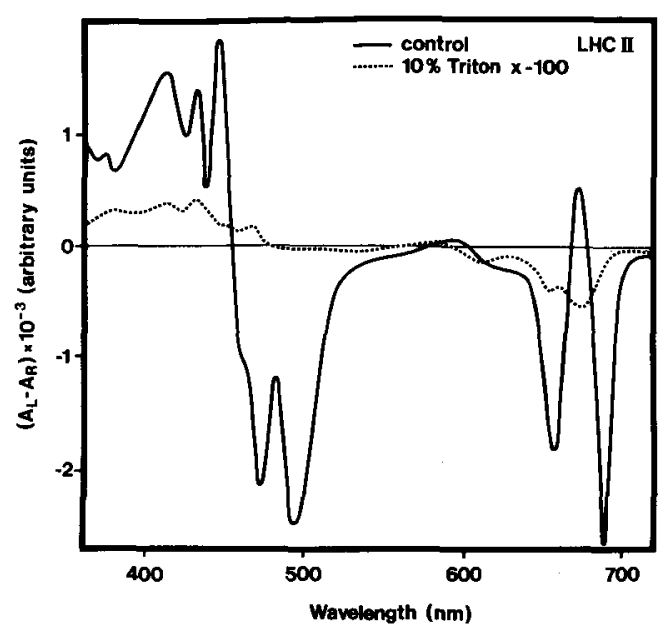

Figure 1. CD spectrum of purified LHCII in its native state, and after denaturation by $10 \%$ Triton X-100.

\section{RESULTS}

\subsection{Chlorophyll content of purified LHCII}

LHCII was isolated by sucrose density gradient centrifugation of PSII membranes solubilized with dodecyl- $\beta, D-$ maltoside as described previously (14). Native preparations had strong $\mathrm{CD}$ signals in the red that are attributed to $\mathrm{Chl}$ $a(688 \mathrm{~nm})$ and $\mathrm{Chl} b(657 \mathrm{~nm})$, respectively (Figure 1). The ratio of these signals was the same as the spectroscopically determined $\mathrm{Chl}$ $a / \mathrm{Chl} b$ ratio of $1.40(\mathrm{w} / \mathrm{w})$. Denatured LHCII had much weaker CD signals which were due to the intrinsic dichroism of the pigments and the peaks were shifted to shorter wavelengths.

The number of $\mathrm{Chl}$ molecules bound per polypeptide was determined using amino acid analysis to quantitate the protein. Colorimetric assays were found to give unreliable estimates of the concentration of Chl-proteins. We found $13.1 \pm 2.4 \mathrm{Chl}$ molecules per $25 \mathrm{kD}$ polypeptide (molecular weight of the mature polypeptide calculated from the amino acid sequence deduced from the nucleotide sequence of a corresponding gene in wheat (18)). Assuming that there are five component polypeptides of LHCII and all bind $\mathrm{Chl}$, this gives about $65 \mathrm{Chl}$ molecules per oligomer. The preparation had a molar Chl $a / b$ ratio of $1.37 \pm 0.05$ and $5.5 \pm 1.0$ 

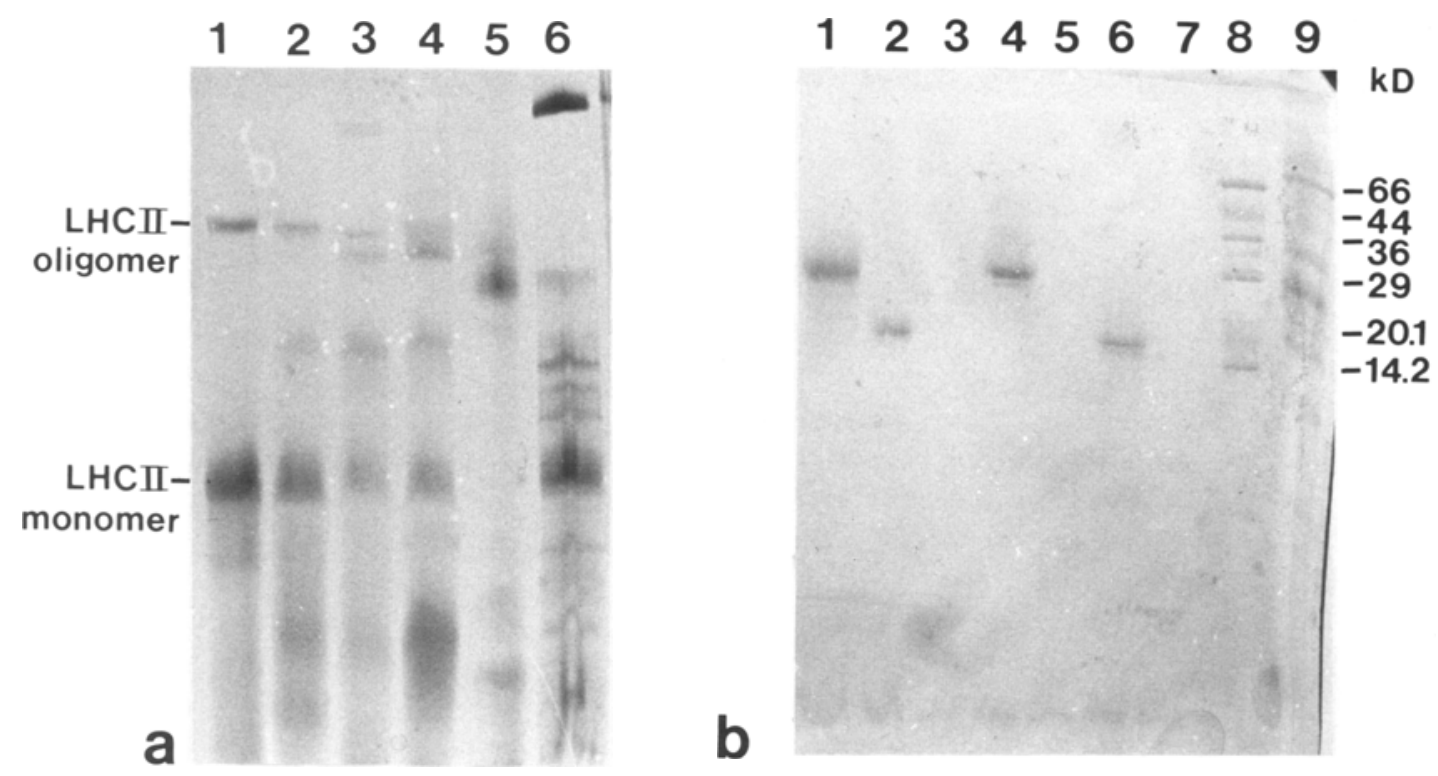

Figure 2. SDS-PAGE of protease-treated LHCII under (a) non-denaturing conditions and (b) after boiling in SDS and run under denaturing conditions in the presence of $6 \mathrm{M}$-urea. For (a) LHCII was added to the gel without removing the proteases, whereas for (b) protease-treated LHCII was purified by sucrose gradient centrifugation before SDS-PAGE.

A) Lane 1: LHCII control, Lane 2: LHCII incubated with trypsin, Lane 3: LHCII incubated with chymotrypsin, Lane 4: LHCII incubated with subtilisin, Lane 5: molecular weight markers, Lane 6: wild type thylakoid membranes.

B) Lane 1: LHCII control, Lane 2: LHCII incubated with trypsin, Lane 3: LHCII incubated with protease K, Lane 4: LHCII incubated with Staph. aureus protease V8, Lane 5: LHCII incubated with pronase E, Lane 6: LHCII incubated with chymotrypsin, Lane 7: LHCII incubated with subtilisin, Lane 8: molecular weight markers, Lane 9: wild type thylakoid membranes.

molecules $\mathrm{Chl} b$ and $7.6 \pm 1.4$ molecules $\mathrm{Chl} \mathrm{a}$ per $25 \mathrm{kD}$ polypeptide.

\subsection{Proteolytic digestion and the domain structure of LHCII}

When purified LHCII was treated with proteases, non-denaturing SDS-PAGE showed green bands with a slightly higher mobility than the control (Figure 2a). The difference in mobility was minimal, regardless of which protease had been used. Using high concentrations of protease or incubation times up to $48 \mathrm{~h}$ at $4{ }^{\circ} \mathrm{C}$ did not give rise to smaller green fragments, and the amount of Chl-protein was unchanged as judged by non-denaturing SDS-PAGE.

When LHCII was digested with trypsin or chymotrypsin prior to SDS-PAGE under dena- turing conditions, only one fragment of $16 \mathrm{kD}$ was visible, indicating that the rest of the polypeptide chain had been degraded to peptides of less than 2-3 kD (Figure 2b). This $16 \mathrm{kD}$ fragment was not further digested when very large amounts of trypsin or chymotrypsin were used, suggesting that it forms a tightly folded domain.

Treatment with low amounts of subtilisin A yielded a fragment with the same mobility during SDS-PAGE under denaturing conditions. Exposure to high concentrations of subtilisin $\mathrm{A}$, pronase $\mathrm{E}$ or protease $\mathrm{K}$ degraded LHCII into peptides that were too small to be detected on SDS-polyacrylamide gels (Figure $2 b$ ). There was, nevertheless, no apparent change in the amount or mobility of the green protein band during non-denaturing SDS-PAGE beyond that 
induced by trypsin-treatment, showing that LHCII was held together by non-covalent interactions even though the polypeptide backbone had been cleaved in several places.

Higher oligomers of LHCII were observed after non-denaturing SDS-PAGE in the digested material as well as the control. After protease treatment, the mobility of the oligomers was also slightly changed, indicating that the oligomers were not composed of undigested material. Since most of the LHCII dissociated into the monomeric form even under non-denaturing electrophoretic conditions, we used gel-filtration to study the effect of proteolytic digestion on the structure of LHCII. An AcA 34 column was equilibrated in $0.05 \%$ SDS, $100 \mathrm{mM}-\mathrm{NaH}$ $\mathrm{CO}_{3}$, pH 9.0, 0.5 mM-DTT and calibrated separately with blue dextran 2000 , thyroglobulin $(669 \mathrm{kD})$, ferritin $(440 \mathrm{kD})$, catalase (232 kD), aldolase (158 kD), bovine serum albumin (67 $\mathrm{kD})$ and ovalbumin (43 kD) as standards. Nondenatured LHCII migrated as a complex with an apparent molecular weight of $275-300 \mathrm{kD}$ both before and after proteolysis, thus demonstrating that protease-treatment did not remove peptides that were important for the stability of the oligomers. Raising the SDS concentration to $0.1 \%$ did not change the elution point of oligomeric LHCII.

The molecular weight determined by gel-filtration is higher than that calculated from the apparent molecular weights of the five component polypeptides of maize LHCII (143 kD) (6). The addition of 6 acyl lipid molecules (27) and $13 \mathrm{Chl}$ molecules per subunit, gives $225 \mathrm{kD}$. The reason for this discrepancy is not clear, but it is conceivable that barley LHCII could contain 6 or 7 homologous polypeptides.

\subsection{N-terminal amino acid sequence of the $\mathbf{1 6}$ kD fragment}

To determine which part of the polypeptide chain was contained in the $16 \mathrm{kD}$ tryptic fragment, we determined its $\mathrm{N}$-terminal amino acid sequence (four separate analyses) and aligned it with the amino acid sequences that have been deduced from the nucleotide sequences of the corresponding genes.

Trypsin-treated LHCII was purified either by

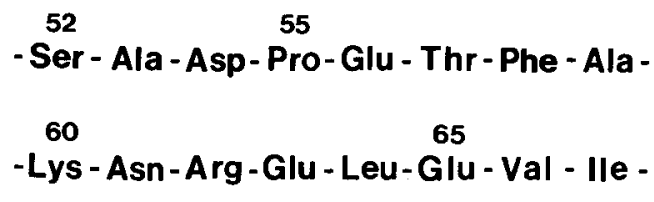

Figure 3. N-terminal amino acid sequence analysis of the $16 \mathrm{kD}$ tryptic fragment from LHCII. Comparison with the amino acid sequence deduced from the nucleotide sequence of the corresponding gene in wheat (18) showed that this fragment started with amino acid 52 of the mature protein.

sucrose density gradient centrifugation or by eluting the protein from unstained gel slices after denaturing SDS-PAGE. In both cases the protein was separated from buffer components and small peptides by gel-filtration on an AcA 34 column equilibrated in $0.05 \%$ SDS, 100 mM- $\mathrm{NaHCO}_{3} \mathrm{pH}$ 9.0, 0.5 mM-DTT. Samples prepared by gradient centrifugation had a lower background during sequence analysis than those eluted from gels. The N-terminal amino acid sequence ( 16 residues) of the $16 \mathrm{kD}$ fragment (Figure 3) was identical to the amino acid sequence deduced from the nucleotide sequence of the corresponding gene from wheat (18), beginning with amino acid 52 of the mature polypeptide, or 14 amino acids in front of the first transmembrane helix predicted by KaRLINNEUMANN et al. (15).

At each sequencing step there were several minor PTH-amino acid peaks in addition to the main peak. This may be due to contamination by small peptides that were not completely removed by gel-filtration. Another possibility is that the trypsin was contaminated with traces of other proteases, or that the high amount of trypsin used to ensure complete digestion (1 $\left.\mathrm{mg} \cdot \mathrm{ml}^{-1}\right)$ and the low incubation temperature may have caused self-digestion and lower specificity of the trypsin. Trypsin normally cleaves on the C-terminal side of lysine and arginine residues. The fact that the amino acid immediately before serine 52 (the first amino acid of the $16 \mathrm{kD}$ fragment) is leucine (18) suggests that a certain amount of chymotrypsinlike digestion occurred. 


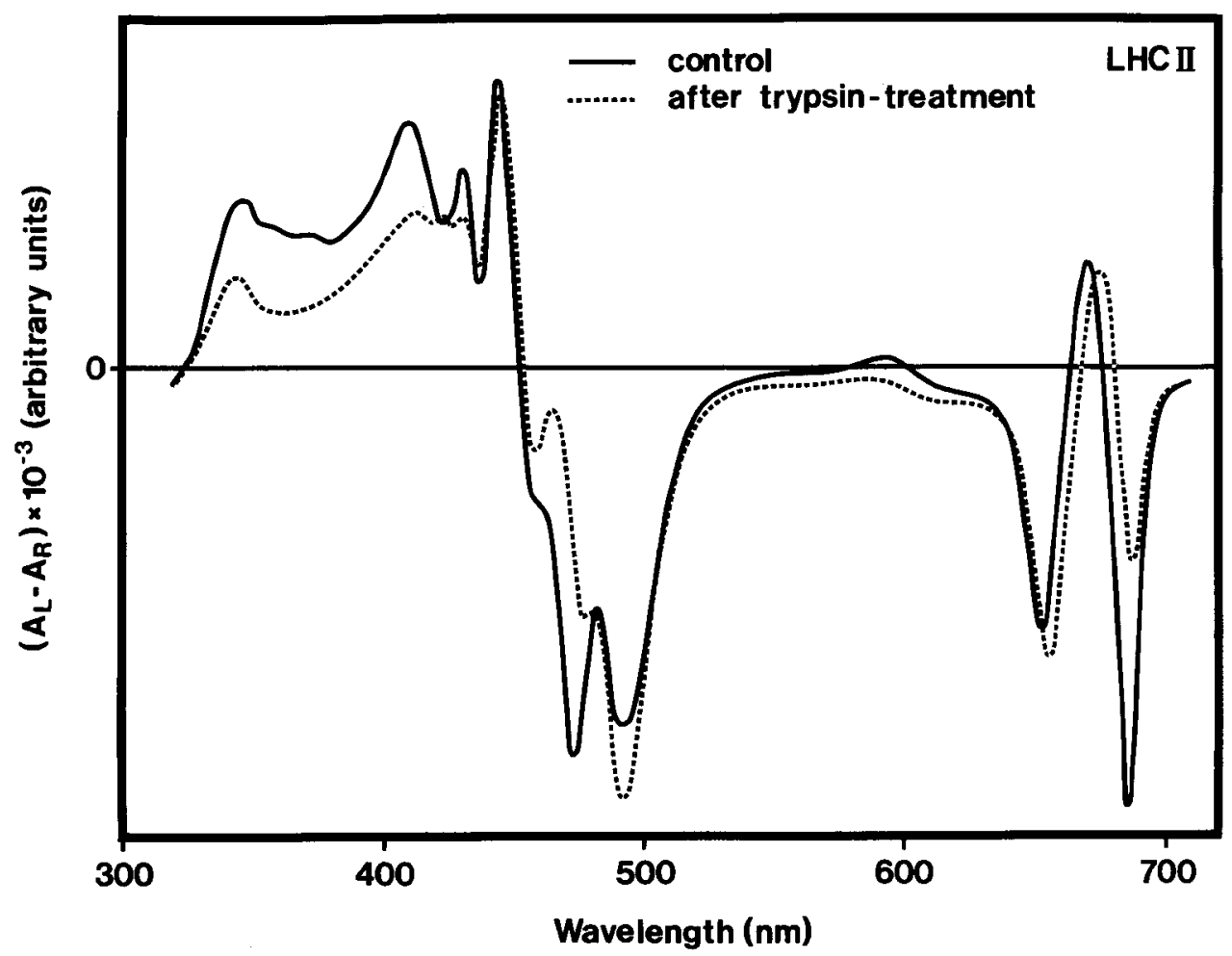

Figure 4. CD spectrum of purified LHCII before and after trypsin-treatment.

\subsection{Changes in the pigment organization in trypsinized LHCII}

Circular dichroism spectra of trypsin-treated LHCII indicated that the organization of Chl $a$ was disturbed, as shown by a $56 \%$ decrease of the signal at $688 \mathrm{~nm}$ (Figure 4). Moreover, there was a change in the ratio of the signals at 476 and 493 $\mathrm{nm}$ and a general loss of detail at lower wavelengths. In contrast, the organization of $\mathrm{Chl} b$ appeared to be unchanged, since there was no decrease in the intensity of the signal at $657 \mathrm{~nm}$. These results suggest that some of the $\mathrm{Chl} a$ and xanthophyll molecules are bound close to the outer surface of LHCII, and hence the thylakoid membrane, and that $\mathrm{Chl} b$ is organized in the core of LHCII.

After proteolytic treatment the molar $\mathrm{Chl} a / b$ ratio had decreased from $1.37 \pm 0.05$ to $1.25 \pm$ 0.04 , and the protein/Chl ratio $(\mathrm{w} / \mathrm{w})$ had decreased from $2.20 \pm 0.46$ to $1.50 \pm 0.51$. The number of Chl $b$ molecules (after protease-treat- ment) was calculated to be $5.3 \pm 2$ per $16 \mathrm{kD}$ polypeptide chain (which is the same molar ratio as the untreated sample), and there were 6.6 molecules of $\mathrm{Chl} a$, indicating that one molecule of Chl $a$ per polypeptide was lost.

\subsection{Effects of SDS on pigment organization and oligomeric structure in LHCII}

Circular dichroism spectroscopy showed that SDS induced rapid changes in the organization of the pigments. Within $3 \mathrm{~min}$ of the addition of SDS to a final concentration of $1 \%$, the intensity of the Chl $a$ signal at $688 \mathrm{~nm}$ had diminished by more than $50 \%$ (Figure 5). There were also dramatic changes in the ratio of the signals at 476 and $493 \mathrm{~nm}$ and a general loss of detail at lower wavelengths, similar to those observed after trypsin treatment. In contrast, the $\mathrm{Chl} b$ signal at $657 \mathrm{~nm}$ and the peak at $674 \mathrm{~nm}$ were almost unchanged. Upon prolonged exposure to 


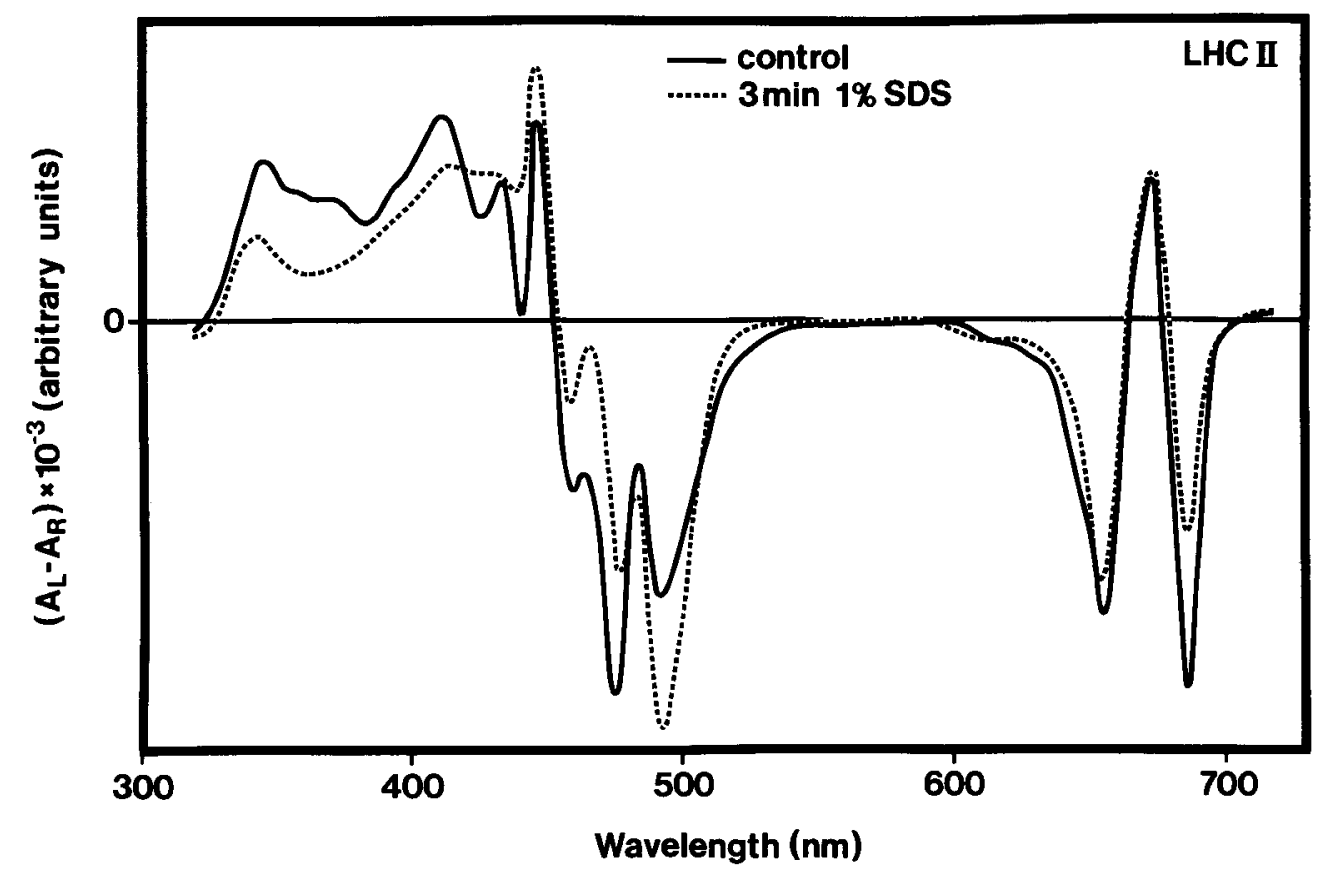

Figure 5. CD spectrum of purified LHCII before and $3 \mathrm{~min}$ after the addition of SDS to a final concentration of $1 \%$.

$1 \%$ SDS these two signals slowly decreased with the same kinetics (Figure 6) and after $2 \mathrm{~h}$ the two signals still had 77 and $74 \%$ of their original intensity. After the first rapid decrease, the $\mathrm{Chl}$ $a$ signal diminished with the same slow rate as the signals at 657 and $674 \mathrm{~nm}$, indicating that there are at least two populations of Chl $a$. After $2 \mathrm{~h}$ the signal at $688 \mathrm{~nm}$ retained $18 \%$ of its original intensity.

The changes observed in the CD spectrum between 460 and $500 \mathrm{~nm}$ upon incubation in $1 \%$ SDS or trypsinization are similar to the differences between the $\mathrm{CD}$ spectrum of oligomeric and monomeric LHCII isolated by non-denaturing SDS-PAGE (4). To test whether these changes were caused by the dissociation of LHCII into monomers, LHCII was incubated in $1 \%$ SDS for up to $30 \mathrm{~min}$ and then applied to an AcA 34 gel-filtration column equilibrated in $0.1 \%$ SDS, 100 mM-NaHCO 3 , pH 9.0, 0.5 mMDTT. The protein eluted as a sharp peak with an apparent molecular weight of 275-300 kD and there was little free $\mathrm{Chl}$ or monomer. Thus the changes in the CD spectrum are not due to the dissociation of oligomeric LHCII into monomers, but to the destabilizing effect of SDS on the Chl organization of LHCII.

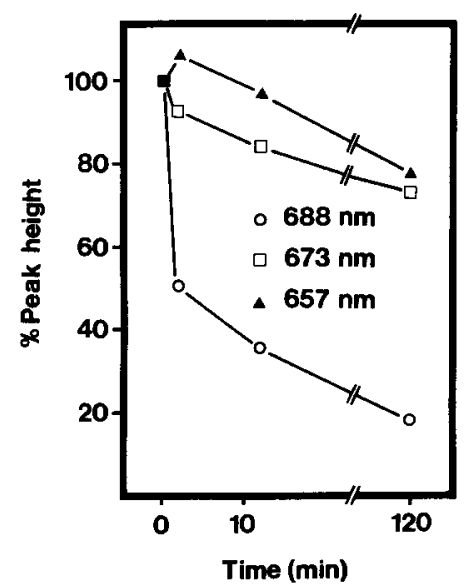

Figure 6. Time course of the denaturation of LHCII in $1 \%$ SDS measured by the decrease in the intensity of the CD signals in the red region. 


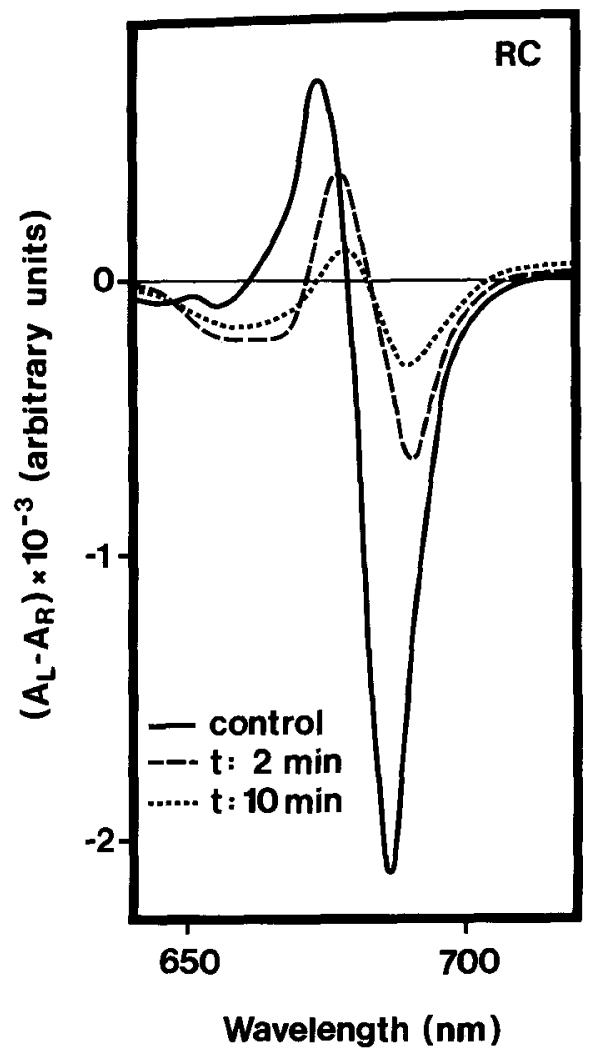

Figure 7. $\mathrm{CD}$ spectra of the undenatured photosystem II reaction center $(\mathrm{RC})$ and the $\mathrm{RC}$ after 2 and $10 \mathrm{~min}$ incubation in $1 \%$ SDS.

\subsection{Denaturation of the reaction center complex of PSII by SDS}

A reaction center complex ( $R C$ ) of photosystem II, composed of $\mathrm{Chl}_{a}$-protein 2, $\mathrm{Chl}_{a}$ protein 3 , cytochrome $b_{559}$, a 32 and a $34 \mathrm{kD}$ polypeptide, most of the $33 \mathrm{kD}$ polypeptide from the oxygen-evolving site plus ca 19 lipid molecules was isolated by sucrose density gradient centrifugation of PSII membranes solubilized with dodecyl-maltoside (14). The reaction center complex was much more sensitive to SDS than LHCII. Incubation in $1 \%$ SDS rapidly decreased the degree of pigment organization, as shown by the diminishing intensity and the broadening of the $C D$ signals at 673 and $686 \mathrm{~nm}$ (Figure 7). After $10 \mathrm{~min}$ there was only a small residual $C D$ signal, but the $C h l$ still retained some organization since the peak had not shifted to the blue and there was still exciton splitting. Correlated with these changes in the CD spectrum, RC lost the ability to transport electrons from the artificial donor diphenyl carbazide to the acceptor dichlorophenol indophenol and was totally inactive after $5 \mathrm{~min}$.

\section{7. pH stability of LHCII}

LHCII was incubated for $2 \mathrm{~h}$ at $4{ }^{\circ} \mathrm{C}$ at different $\mathrm{pH}$ values before recording the $\mathrm{CD}$ spectra. Between $\mathrm{pH} 3.5$ and 10.5 no change in the pigment organization could be detected. At $\mathrm{pH} 11$ the signals at 658 and $688 \mathrm{~nm}$ had diminished by 5 and $33 \%$, respectively, and at $\mathrm{pH} 12$ the intensity of the signals had further decreased to 45 and $18 \%$ of their original intensity and the negative peak at $657 \mathrm{~nm}$ had become much broader (Figures 8 and 9). Samples that had been incubated at $\mathrm{pH} 12$ showed only free pigment during non-denaturing SDS-PAGE in tube gels (not shown), indicating that although the complex retained some degree of pigment organization, it had become very unstable.

At low pH the signal at $688 \mathrm{~nm}$ also started decreasing before that at $657 \mathrm{~nm}$, confirming

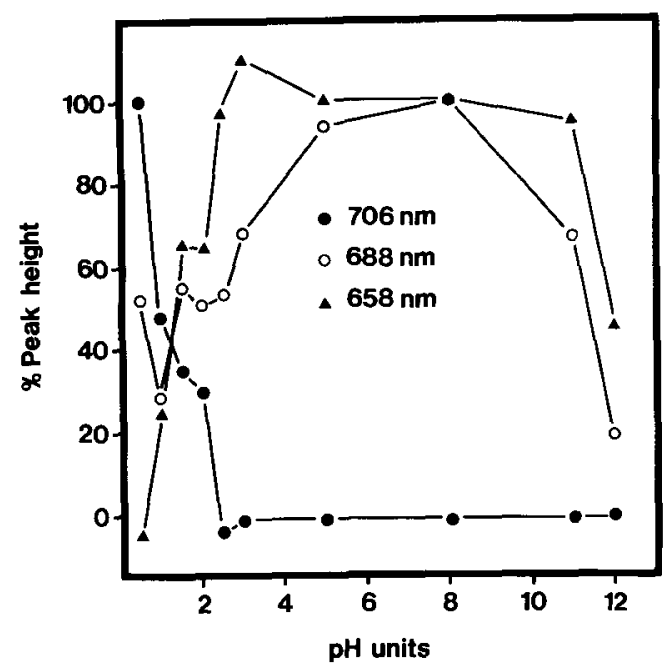

Figure 8. pH-dependent changes in the pigment organization of LHCII measured by CD spectroscopy. The spectrum of undenatured $\mathrm{LHCII}$ at $\mathrm{pH} 8.0$ was taken as the reference. 
U. G. HINZ \& K. G. WELINDER: Structure and chlorophyll organization of LHCII
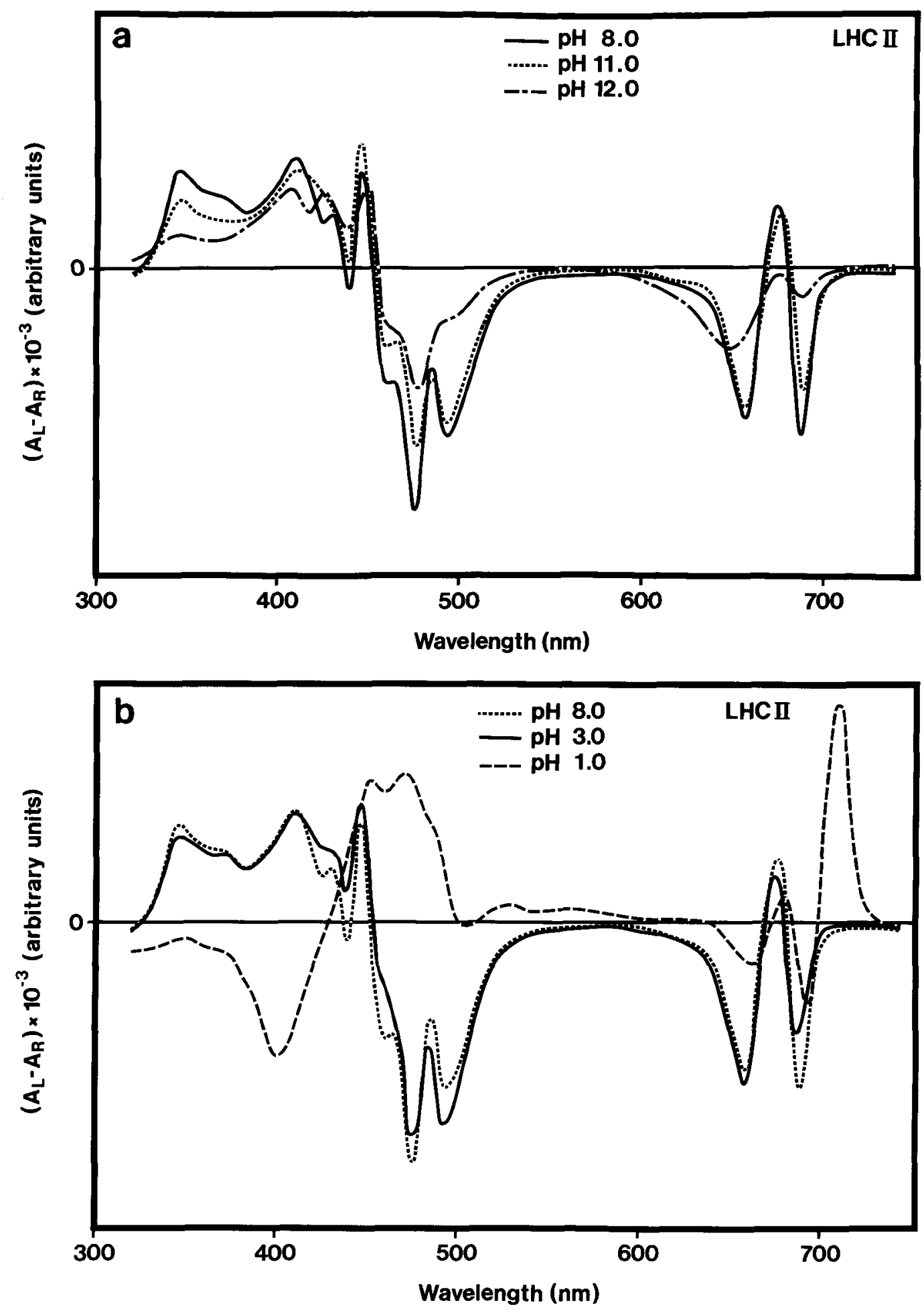

Figure 9. CD spectrum of $\mathrm{LHCII}$ after $2 \mathrm{~h}$ incubation at $4{ }^{\circ} \mathrm{C}$ at (a) $\mathrm{pH} 8.0$ (control), $\mathrm{pH} 11.0$ and $\mathrm{pH} 12.0$, and at (b) $\mathrm{pH} 8.0, \mathrm{pH} 3.0$ and $\mathrm{pH} 1.0$. 


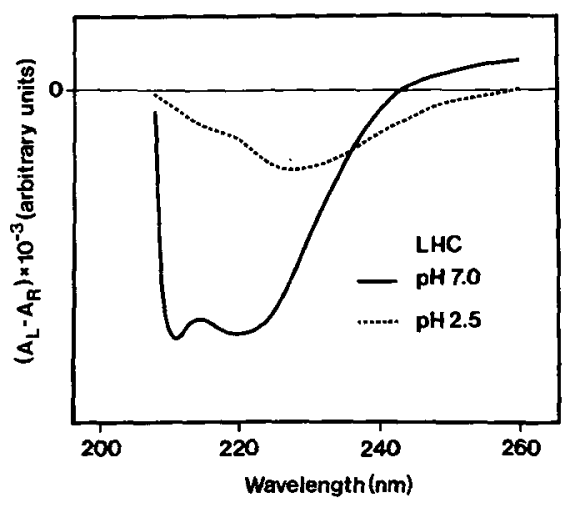

Figure 10. Ultraviolet CD spectrum of native LHCII and LHCII incubated for $2 \mathrm{~h}$ at $4{ }^{\circ} \mathrm{C}$ at $\mathrm{pH} 2.5$. that $\mathrm{Chl} a$ is more accessible from the water phase than $\mathrm{Chl} b$. After $2 \mathrm{~h}$ incubation at $\mathrm{pH} 3.0$ the organization of Chl $b$ was apparently unchanged, but the Chl $a$ signal at $688 \mathrm{~nm}$ had decreased by $32 \%$. Moreover, there was a change in the ratio of the signals at 476 and $492 \mathrm{~nm}$, similar to that observed upon incubation in $1 \%$ SDS or proteolysis.

At $\mathrm{pH}$ values below 2.5 the signal at $657 \mathrm{~nm}$ decreased rapidly, suggesting that the protein was unfolding. This was confirmed by measuring CD spectra between 260 and $200 \mathrm{~nm}$ (Figure 10). The decrease in ellipticity at 208 and 222 $\mathrm{nm}$ was indicative of a pronounced decrease in the amount of $\alpha$-helix. However, the amplitude

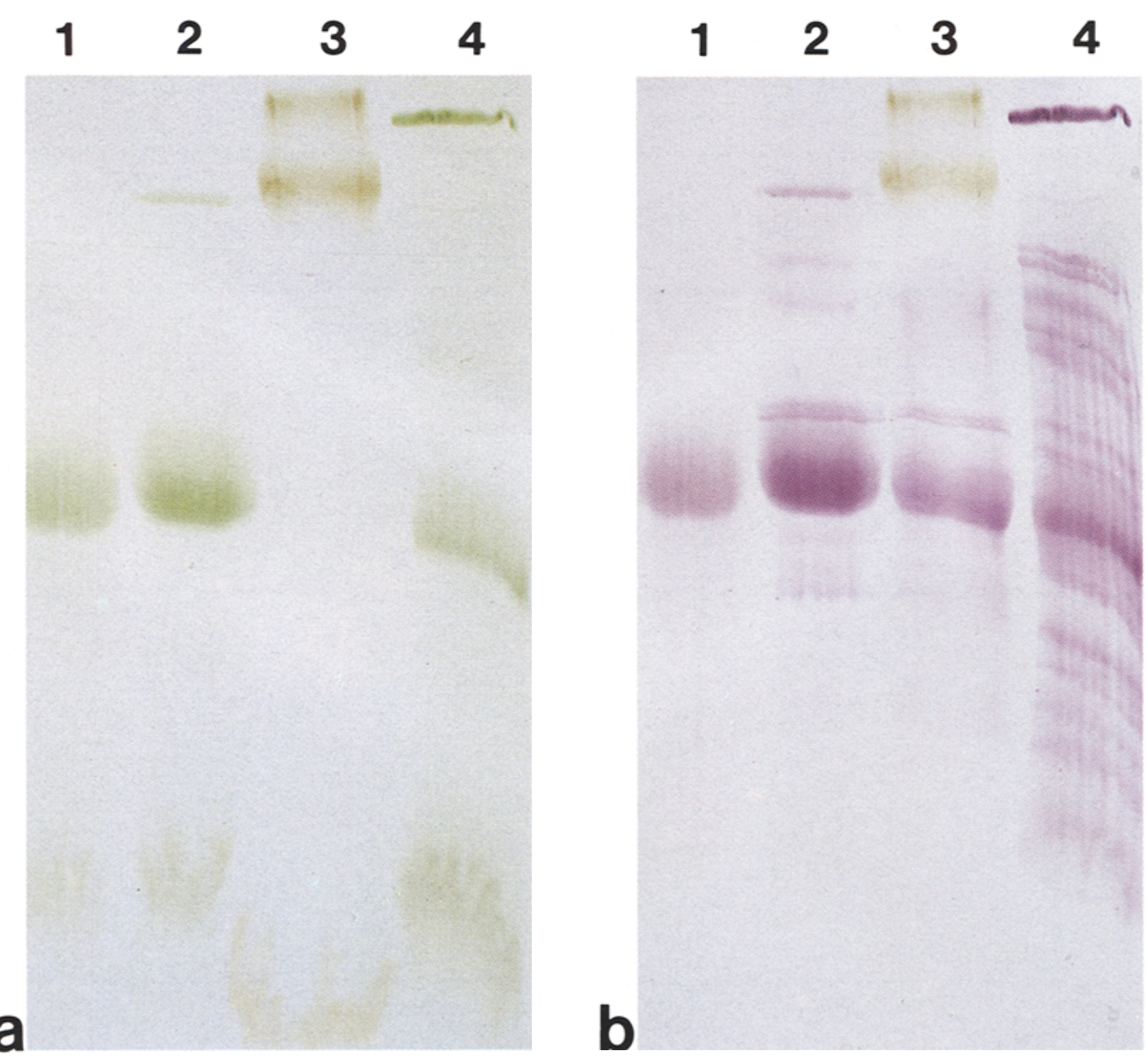

Figure 11. Polyacrylamide gel (A) before and (B) after staining with Coomassie brilliant blue. Proteins were separated by non-denaturing SDS-PAGE at $2{ }^{\circ} \mathrm{C}$ using buffer system II (20). Lane 1: LHCII after trypsin treatment. Lane 2: LHCII control, Lane 3: LHCII after $2 \mathrm{~h}$ incubation at pH 1.5, Lane 4: wild type thylakoid membranes. 

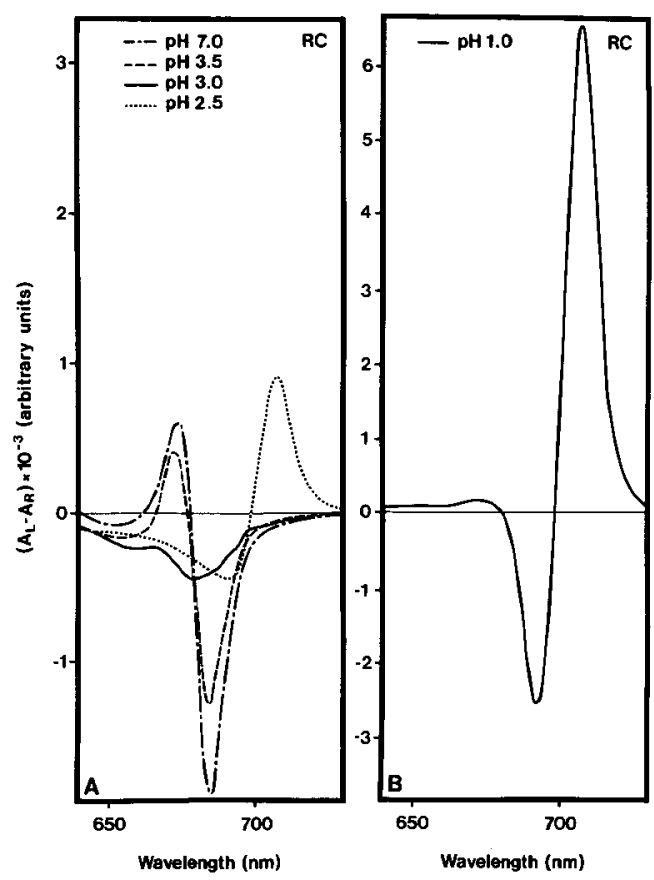

Figure 12. Denaturation of $\mathrm{RC}$ at low $\mathrm{pH}$ measured by CD spectroscopy. Spectra were recorded after incubation for $2 \mathrm{~h}$ at (a) $\mathrm{pH} 7.0(\cdot-\cdot-\cdot-\cdot)$, $\mathrm{pH} 3.5(--\cdot-)$, $\mathrm{pH} 3.0(-)$ and $\mathrm{pH} 2.5(\cdots \cdots \cdots . . .$.$) and (\mathrm{b}) \mathrm{pH} 1.0$. The latter spectrum is drawn to a different scale.

of the signal at $688 \mathrm{~nm}$ did not decrease further, but shifted to $690 \mathrm{~nm}$, and a new peak was observed at $706 \mathrm{~nm}$ when the $\mathrm{pH}$ was lowered below 2.5 . This new signal increased in intensity as the $\mathrm{pH}$ was lowered to 0.5 . Below $\mathrm{pH} 1.5$, the $\mathrm{Chl}$ was completely pheophytinized and there were strong new CD signals at 400,444 and 468 $\mathrm{nm}$. SDS-PAGE showed that the pigments were no longer'associated with the protein (Figure 11). Instead, there was a pheophytin aggregate to which the new $C D$ signals are attributed.

\section{8. pH stability of RC}

The pigment organization of $\mathrm{RC}$ remained unchanged over a wide $\mathrm{pH}$ range. The $\mathrm{Chl}$ was still bound at pH 12 as judged by non-denaturing tube gel electrophoresis (not shown), but became unstable below pH 4 (Figure 12). At pH 3.5 the negative peak at $686 \mathrm{~nm}$ retained $67 \%$ of

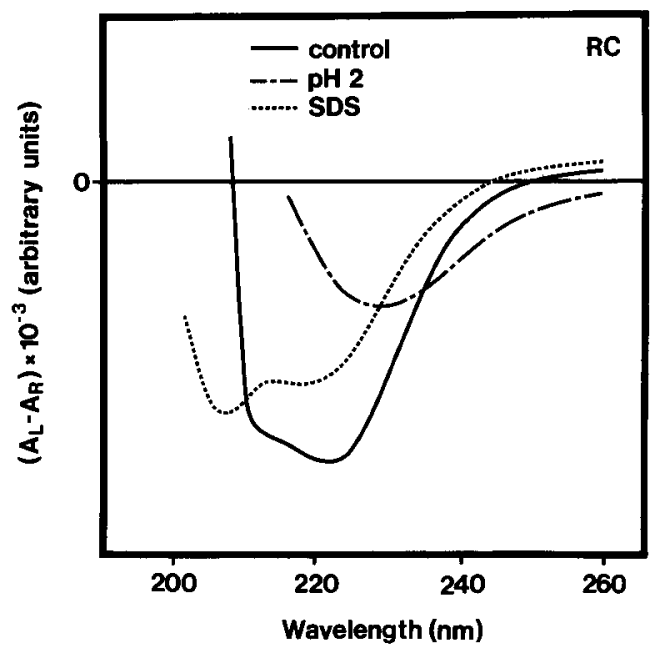

Figure 13. Ultraviolet CD spectrum of native photosystem II reaction center (RC) and RC incubated for 2 h at $4^{\circ} \mathrm{C}$ at $\mathrm{pH} 2.0$.

its original intensity, but at pH 3.0 the $\mathrm{Chl}$ was completely disorganized as evidenced by the very broad trough, the blue-shift and the absence of exciton splitting. $C D$ measurements in the UV range (Figure 13) showed a decrease in the ellipticity at 208 and $222 \mathrm{~nm}$ at pH 2.0, indicating unfolding of the $\alpha$-helices and confirming that the protein was denatured.

As found for LHCII, a new signal at $706 \mathrm{~nm}$ appeared when the $\mathrm{pH}$ was lowered to 2.5 or less. The intensity of the signal increased as the $\mathrm{pH}$ decreased. This signal, which had a positive component at $706 \mathrm{~nm}$ and a smaller negative component at $690 \mathrm{~nm}$, was attributed to pheophytin aggregates.

\section{DISCUSSION}

LHCII has been shown to be composed of at least five polypeptides in maize (5). Proteolytic digestion studies indicated that LHCII is an extremely stable complex held together by noncovalent interactions - presumably hydrogen bonding between charged or polar residues buried in the membrane - even when the polypeptide chain was cleaved in so many places that the peptides were too small to be detected after electrophoresis under denaturing condi- 
tions on polyacrylamide gels containing $6 \mathrm{M}$ urea. The same preparation showed only a slight increase in the mobility of the green band during non-denaturing SDS-PAGE.

Despite the fact that intact LHCII can be resolved into five polypeptide bands by SDSPAGE under denaturing conditions (5), a single fragment with an apparent molecular weight of $16 \mathrm{kD}$ was observed after digestion with trypsin or chymotrypsin. Amino acid sequence analysis and comparison with the amino acid sequence derived from wheat (18) showed that the $16 \mathrm{kD}$ fragment started with residue 52 of the mature polypeptide chain. The amino acid sequences deduced from the nucleotide sequences of the genes coding for LHCII polypeptides in Lemna gibba (15), wheat (18), tomato (26) and pea (11) are more than $90 \%$ identical, and the first 16 residues of the $16 \mathrm{kD}$ tryptic fragment from barley are identical to those of wheat, pea and tomato. This suggests that several polypeptide components of LHCII in barley could give rise to tryptic fragments with identical $\mathrm{N}$-terminal sequences.

Determination of the Chl content of LHCII showed that it binds an average of $13.1 \pm 2.4$ Chl molecules per $25 \mathrm{kD}$ polypeptide or $5.5 \pm$ 1.0 molecules $\mathrm{Chl} b$ and $7.6 \pm 1.4$ molecules $\mathrm{Chl}$ $a$. Rounding to the nearest integer gives 6 molecules of Chl $b$ and 8 molecules of Chl $a$ per $25 \mathrm{kD}$ and $\mathrm{a} \mathrm{Chl} a / b$ ratio of 1.33 . Alternatively, there might be 5 molecules of $\mathrm{Chl} b$ and 7 molecules of Chl $a$ with a Chl $a / b$ ratio of 1.40 . On the basis of our data it was not possible to decide between these possibilities. It has been assumed in these calculations that all of the component polypeptides of LHCII bind Chl equally. Spectroscopic data have indicated that Chl $b$ molecules in LHCII monomers are oriented around a three-fold symmetry axis $(13,28$, 30). This means that the $\mathrm{Chl} b$ molecules are either organized in multiples of three, or that there are three $\mathrm{Chl} b$ molecules around a threefold symmetry axis plus two or three separately organized $\mathrm{Chl} b$ molecules. The latter hypothesis is supported by the existence of a slight shoulder on the $\mathrm{Chl} b \mathrm{CD}$ signal in the red.

Trypsin-treated material had a lower Chl $a / b$ ratio $(1.25 \pm 0.04$ vs $1.37 \pm 0.05)$, and the protein/Chl ratio $(w / w)$ had changed from 2.20 \pm 0.46 to $1.50 \pm 0.51$, indicating the loss of one molecule of Chl $a$ per polypeptide. Circular dichroism spectra in the visible range indicated that the organization of $\mathrm{Chl} a$ and xanthophylls had been affected, but there was no change in the organization of $\mathrm{Chl} b$. This means that with the exception of one $\mathrm{Chl} a$ molecule, all of the $\mathrm{Chl}$ is bound to the $16 \mathrm{kD}$ tryptic fragment of LHCII.

When LHCII was incubated in $1 \%$ SDS or at extremes of $\mathrm{pH}$ the organization of $\mathrm{Chl} a$ and xanthophylls was disturbed before that of $\mathrm{Chl} b$. Since these treatments did not cause the dissociation of LHCII into its subunits, this means that part of the $\mathrm{Chl} a$ and xanthophyll molecules are organized in that part of the protein that is normally exposed to the outer surface of the thylakoid membrane, so these pigment molecules could mediate excitation transfer between adjacent membranes.

Assigning CD signals to specific pigment species has been difficult since interactions between pigments and between pigments and the polypeptide chain induce exciton splitting and shifts in the peak wavelengths. Thus the peak at $674 \mathrm{~nm}$ has been alternatively attributed to $\mathrm{Chl}$ $a(8)$ or to exciton splitting due to interactions between $\mathrm{Chl} b$ trimers $(13,28,30)$. The latter model was based on spectra of monomeric LHCII isolated by preparative SDS-PAGE, where the $\mathrm{CD}$ signals due to $\mathrm{Chl} a$ were nearly non-existent. The different resistance to SDS and the kinetics of disappearance of the signals at 688,674 and $657 \mathrm{~nm}$ indicate that the peak at $674 \mathrm{~nm}$ is indeed mainly due to exciton splitting between $\mathrm{Chl} b$ molecules, but one cannot exclude a possible contribution from $\mathrm{Chl}$ $a$.

Analysis of two-dimensional crystals of LHCII preparations with the electron microscope indicated that each polypeptide subunit contained three or four transmembrane helices (16). KARLIN-NEUMANN et al. (15) proposed a model for the folding of an LHCII polypeptide with three transmembrane helices. This model was based on hydropathy plots and left large parts of the polypeptide chain exposed to the water phase, and thus potentially accessible to proteolytic digestion. In contrast, we found that the $16 \mathrm{kD}$ fragment was not degraded to smaller fragments by high concentrations of trypsin or 


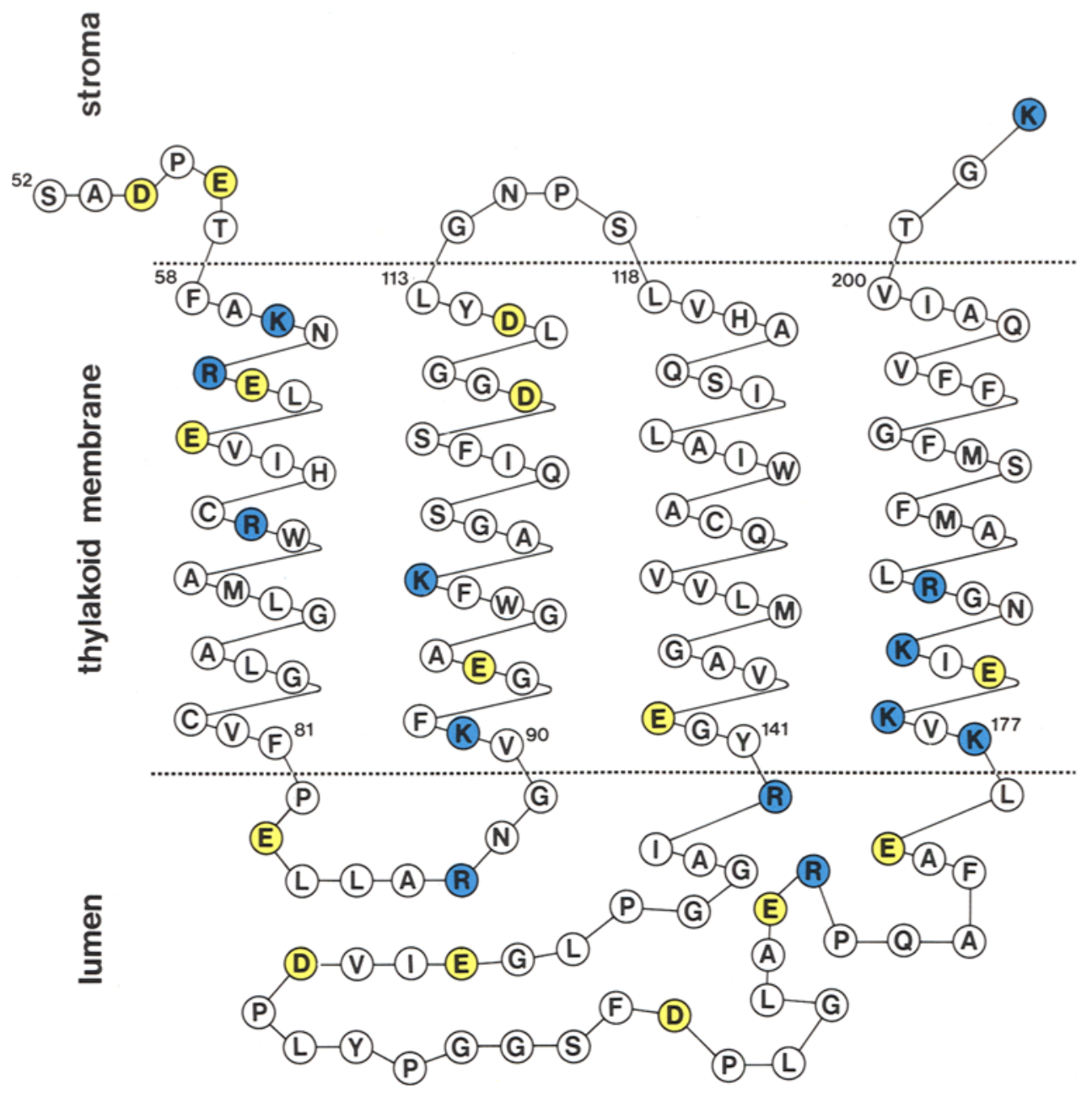

Figure 14. Tentative model for the folding of the $16 \mathrm{kD}$ tryptic fragment of LHCII, based on the sequence deduced for wheat. Aspartic acid and glutamic acid residues are coloured yellow, lysine and arginine are coloured blue.

chymotrypsin, indicating that it forms a compact domain. No other fragments could be detected, suggesting that the $\mathrm{N}$ - and $\mathrm{C}$-terminal parts of the polypeptide chain had been degraded to peptides of less than $2-3 \mathrm{kD}$.

Since the $16 \mathrm{kD}$ fragment contained all but one of the $\mathrm{Chl}$ molecules bound per $25 \mathrm{kD}$ LHCII polypeptide, we thought it of interest to draw a tentative model of the folding of the 16 kD fragment. Knowing from spectroscopic measurements that LHCII had a high content of alpha-helical structure $(14,23)$ we assumed that the polypeptide chain crossed the membrane in helical conformation, as is the case for bacteriorhodopsin or the bacterial reaction center complex, and that each membrane-spanning segment contained 24 amino acid residues. Turns were predicted by the method of PAUL and ROSENBUSCH (24) which is specifically designed for use with membrane proteins. Since residues in turn positions are assumed to be at the surface of the protein and in contact with the water phase, we also applied the rules of $\mathrm{CHOU}$ and FASMAN (10) for the prediction of beta-turns. 
Both methods indicated identical turn positions when they were applied to the amino acid sequence deduced from the nucleotide sequence of the corresponding gene in wheat (18). Comparison with sequences from other species (pea, petunia, tomato and Lemna gibba) showed that with one exception, the deduced amino acid sequences were identical at the predicted turn positions and that this amino acid substitution did not change the result of the prediction. By this method we obtained a model with four transmembrane helices, where both the $\mathrm{N}$ - and C-terminal parts of the polypeptide chain are exposed to the water phase at the outer surface of the membrane (Figure 14). This is in agreement with the results of proteolytic digestion studies by ANDERSSON et al. (2) who showed that LHCII was not digested by trypsin in inside-out thylakoid membrane vesicles, but that trypsintreatment of right-side out vesicles caused a slight increase in the mobility of LHCII. ANDERSON and GOODCHILD (1) have recently obtained evidence that the $\mathrm{N}$ - and $\mathrm{C}$-termini are both located on the stroma surface, using an antibody raised against a synthetic peptide based on the deduced C-terminal sequence.

The first predicted transmembrane helix starts with phenylalanine 58 , immediately after a predicted turn, and eight residues before the beginning of the first helix predicted by KARLINNEUMAN et al. (15). This introduces two glutamic acids and one arginine into the hydrophobic core of the membrane, but since the acidic and basic amino acids are three residues apart, they might form a salt bridge, which would neutralize the charges. In this way, the potential tryptic cleavage sites lysine 60 and arginine 62 could be protected. Alternatively, the charged residues buried in the interior of the membrane might form salt bridges between helices and thereby help to stabilize the complex. The next predicted turn (Figure 14) starts with alanine 86, followed by the second transmembrane helix, beginning with valine 90 . The hydropathy of this segment is compatible with transmembrane localization. Again there are a lysine and a glutamic acid three residues apart whose charges may be neutralized by salt bridges. The next predicted turn starts with glycine 114 . This is followed by the third transmembrane helix starting with leucine 118 , which is identical to the second helix predicted by KarLin-Neuman et al. (15). This segment contains no charged amino acids.

The next part of the sequence is rich in proline and glycine and contains several potential turn sites. We did not attempt to make any detailed prediction for this part of the polypeptide chain. The fourth predicted transmembrane helix starts with lysine 177 and is shifted by nine residues relative to the one predicted by KARLINNEUMAN et al. (15). The projecting helices and loops in the lumen may correspond to the projections seen by KüHLBRANDT (16) upon analysis of two-dimensional crystals in the electron microscope. The apparent molecular weight of the fragment would be compatible with tryptic cleavage at lysine 203 , which is buried in the membrane in the model of KARLINNeuman et al. (15). The electrophoretic mobility of undigested LHCII agrees well with the molecular weight calculated from the deduced amino sequence. However, the tryptic fragment might migrate abnormally during SDS-PAGE, and we cannot exclude that the C-terminal cleavage occurred at some other residue. It should be noted that there are several potential cleavage sites for trypsin and chymotrypsin exposed to the water phase in our model. Their protection against proteolytic digestion must be due to the tightly folded and stable tertiary structure of the polypeptide.

There has been much speculation about how the polypeptide and the Chl molecules interact to achieve the precise organization of the pigment molecules that is important for the function of the Chl-proteins. Histidine residues have been proposed to bond to the central $\mathrm{Mg}$ ion in the porphyrin ring, but the $16 \mathrm{kD}$ tryptic fragment of LHCII contains only two histidine residues. The seven glutamine and asparagine residues in a bacteriochlorophyll $\mathrm{c}$ binding polypeptide from chlorosomes of a green photosynthetic bacterium have been proposed to bind the seven bacteriochlorophyll c molecules (31), but again, there are no striking coincidences of this kind in LHCII. One possibility to determine where the $\mathrm{Chl}$ molecules are bound would be to bind them covalently to the polypeptide chain by means of a chemical crosslinking reagent, to digest the protein to small peptides and to 
determine the position of the modified residues by amino acid sequence analysis. Another method, which is more time-consuming but yields more information about the precise organization of the pigments, is to produce three-dimensional crystals of Chl-proteins and to analyze them by X-ray diffraction. KÜHLBRANDT (17) has recently reported important progress in this respect in that two crystal forms of LHCII have now been prepared.

\section{ACKNOWLEDGEMENTS}

Professor DITER vON WETtSTEIN and Dr. DAVID SIMPSON are thanked for their help and encouragement throughout the stay of $U$. $H$. at the Carlsberg Laboratory. We are grateful to Dr. J. M. ANDERSON for providing us with a copy of the preprint of her paper. IB SVENDSEN, BoDIL CORNELIUSSEN and LONE SøRENSEN are thanked for performing the amino acid analyses. KIRSTEN MiCHELSEN and Sven HARNUNG of the H. C. Orsted Institute, kindly made available the Roussel-Jouen Dichrograph III spectropolarimeter. We also thank PIA JENSEN, NINA RasMUSSEN and ANN-SOFI STEINHOLTZ for expert technical assistance.

\section{REFERENCES}

1. ANDERSON, J. M. \& D. J. GoODCHILD: Lateral heterogeneity of thylakoid complexes and the transverse arrangement of the light-harvesting chlorophyll $\mathbf{a} / \mathbf{b}$-protein of photosystem II of thylakoid membranes. Chemica Scripta. In press (1987)

2. Andersson, B., J. M. Anderson \& I. J. Ryrie: Transbilayer organization of the chlorophyllproteins in spinach thylakoids. Eur. J. Biochem. $123,465-472$ (1982)

3. ARNON; D. I.: Copper enzymes in isolated chloroplasts. Polyphenol-oxidase in Beta vulgaris. Plant Physiol. 24, 1-14 (1949)

4. BASSI, R., O. MACHOLD \& D. J. SimPSON: Chlorophyll-proteins of two photosystem I preparations from maize. Carlsberg Res. Commun. 50, 145-162 (1985)

5. BASSI, R. \& D. J.SIMPSON: Differential expression of LHCII genes in mesophyll and bundle sheath cells of maize. Carlsberg Res. Commun. 51, 363-370 (1986)

6. Bassi. R., D. J. Simpson, R. Barbata, G. HøyerHANSEN \& G. M. GIACOMETTI: The role of LHCII in thylakoid membranes. Proc. 7th Int. Cong. Photosyn., Providence. In press (1986)

7. BERTHOLD, D. A., G. T. BABCOCK \& C. F. YOCUM: A highly resolved, oxygen-evolving photosystem II preparation from spinach thylakoid membranes EPR and electron transport properties. FEBS Lett. 134, 231-234 (1981)

8. Brecht, E. S. Demeter \& A. Faludi-Daniel: Fine structure of the circular dichroic spectrum of the light-harvesting chlorophyll a/b-protein complex reaggregated in vitro. Photobiochem. Photobiophys. 3, 153-157 (1981)

9. Burke, J. J., C. L. DitTo \& C. J. ARntzen: Involvement of the light-harvesting complex in cation regulation of excitation energy distribution in chloroplasts. Arch. Biochem. Biophys. 187, 252263 (1978)

10. ChOu.P. Y.\& G. D. FASMAN: Empirical predictions of protein conformation. Ann. Rev. Biochem. 47, 251-276 (1978)

11. Coruzzi, G., R. Broglie, A. Cashmore \& N. -H. ChUA: Nucleotide sequences of two pea cDNA clones encoding the small subunit of ribulose 1,5-biphosphate carboxylase and the major chlorophyll a/b-binding thylakoid polypeptide. J. Biol. Chem. 258, 1300-1402 (1983)

12. Dunsmuir, P., S. M. SMith \& J. Bedbrook: The major chlorophyll $\mathrm{a} / \mathrm{b}$ binding protein of petunia is composed of several polypeptides encoded by a number of distinct nuclear genes. J. Mol. Appl. Genet. 2, 285-300 (1983)

13. GÜLEN, D. \& R. S. KNOX: Absorption and circular dichroism of the chlorophyll-protein CPII: extensions of a trimeric exciton model. Photobiochem. Photobiophys. 7, 277-286 (1984)

14. HINZ, U. G.: Isolation of the photosystem II reaction center complex from barley. Characterization by circular dichroism spectroscopy and amino acid sequencing. Carlsberg Res. Commun. 50, 285-298 (1985)

15. Karlin-Neumann, G. A., B. D. Kohorn, J. P. THORNBER \& E. A. TOBIN: A chlorophyll a/bprotein encoded by a gene containing an intron with the characteristics of a transposable element. J. Mol. Appl. Gen. 3, 45-61 (1985)

16. KÜHLBRANDT, W.: Three-dimensional structure of the light-harvesting chlorophyll a/b-protein complex. Nature 307, 478-480 (1984)

17. KüHLBRANDT, W.: Crystallization and high resolution structure of the light-harvesting chlorophyll a/b-protein complex. Proc. 7th Int. Cong. Photosyn., Providence. In press (1986)

18. LampPa, G. K., G. MoRelli \& N. -H. ChuA: Structure and developmental regulation of a wheat gene encoding the major chlorophyll $a / b$-binding 
polypeptide. Mol. Cell. Biol. 5, 1370-1378 (1985)

19. LI. J.: Light-harvesting chlorophyll a/b-protein: Three-dimensional structure of a reconstituted membrane lattice in negative stain. Proc. Natl. Acad. Sci. 82, 386-390 (1985)

20. MaChold, O., D. J. Simpson \& B. L. Møller: Chlorophyll proteins of thylakoids from wild type and mutants of barley (Hordeum vulgare). Carlsberg Res. Commun. 44, 235-254 (1979)

21. Mullet, J. E.: The amino acid sequence of the polypeptide segment which regulates membrane adhesion (grana stacking) in chloroplasts. J. Biol. Chem. 258, 9941-9948 (1983)

22. MøLLER, B. L. \& P. B. HøJ: A thylakoid polypeptide involved in the reconstitution of photosynthetic oxygen evolution. Carisberg Res. Commun. 48, 161-185 (1983)

23. Nabedryk, E., S. ANDRIANAmbinintsoA \& J. BreTON: Transmembrane orientation of $\alpha$-helices in the thylakoid membrane and in the light-harvesting complex. A polarized infrared spectroscopy study. Biochim. Biophys. Acta 765, 380-387 (1984)

24. Paul, C. \& J. P. Rosenbusch: Folding patterns of porin and bacteriorhodopsin. EMBO J. 4, 15931597 (1985)

25. Piccioni, R. G., P. Bennoun \& N. -H. Chua: A nuclear mutant of Chlamydomonas reinhardii defective in photosynthetic photophosphorylation. Characterization of the alga coupling factor ATPase. Eur. J. Biochem. 117, 93-102 (1981)

26. PiCherSKY,E., R. BERNATZKy, S. D. TANKSLEy, R. B.
Breidenbach, A. P. Kausch \& A. R. Cashmore: Molecular characterization and genetic mapping of two clusters of genes encoding chlorophyll $\mathrm{a} / \mathrm{b}$-binding proteins in Lycopersicon esculentum (tomato). Gene 40, 247-258 (1985)

27. RaWyler, A., L. E. A Henry \& P. A. Siegenthaler: Acyl and pigment lipid composition of two chlorophyll-proteins. Carlsberg Res. Commun. 45, 443451 (1980)

28. ShePANSKI, J. F. \& R. S. KNox: Circular dichroism and other optical properties of antenna chlorophyll proteins from higher plants. Isr. J. Chem. 21 , 325-331 (1981)

29. Siefermann-Harms, D. \& H. Ninnemann: Pigment organization in the light-harvesting chlorophyll $\mathrm{a} / \mathrm{b}$ protein complex of lettuce chloroplasts. Evidence obtained from protection of the chlorophylls against proton attack and from excitation energy transfer. Photochem. Photobiol. 35, 719 731 (1982)

30. VAN METTER, $R$. L.: Excitation energy transfer in the light-harvesting chlorophyll a/b-protein. Biochim. Biophys. Acta 462, 642-658 (1977)

31. WeChSLER, T., F. SUter, R. C. FULLER \& H. ZUBER: The complete amino acid sequence of the bacteriochlorophyll $\mathrm{c}$ binding polypeptide from chlorosomes of the green photosynthetic bacterium Chloroflexus aurantiacus. FEBS Lett. 181, 173 178 (1985)

32. WRAY, W., T. BOULIKAS, V.P. WRAY \& R. HANCOCK: Silver staining of proteins in polyacrylamide gels. Anal. Biochem. 118, 197-203 (1983) 